\title{
Additions to the Zoophytes of Devonshire.
}

To the Editors of the Annals and Magazine of Natural History.

Gentlemen,-I observe a notice from the Rev. T. Hincks in the 'Annals' for last month, respecting the finding of Sertularia attenuata, Hincks, in North Devon and Cornwall. Mr. Hincks must have forgotten that he had a specimen of mine, for twelve months at least, which was found on the south coast of Devon, and which was not returned to me in time for publication in my 'Catalogue of the Zoophytes of Devonshire.'

I must ask those gentlemen who kindly purchased my 'Catalogue' to add the South Coast to the geographical distribution of this species, and also to add to the freshwater species Plumatella emarginata, Allm., and P. fruticosa, Allm., both of which I met with in the river Clyst, Bishop's Clyst, September 5, 1866.

I am, Gentlemen,
Yours obediently,
EDward ParFitr.
Oct. 6, 1866.

On the Use of the Genus Potamogale. By Dr. J. E. Gray, F.R.S. \&c.

Dr. Günther, in the 'Record of Zoological Literature,' 1865, vol. ii. p. 33, observes, "We fully agree with Dr. Gray as regards the principle on which he objects to the name Potamogale ;" and then proceeds, "but since he has adopted the specific name of velox, given by Du Chaillu at the same time, and as in this case the generic and specific names refer to the same individual specimen, succeeding naturalists have no other choice but to recognize or to reject both alike."

The latter observation is incorrect, and, like several other remarks on mammalia and reptiles in the work, must have been made on a very imperfect recollection of the paper to which they refer. A very cursory inspection of Du Chaillu's paper in the Boston Society's Proceedings (which is copied in the paper commented on in the 'Annals,' vol. xvi. p. 426) would have shown Dr. Günther that the generic name of Potamogale and the specific one of velox do not rest on the same basis. The animal is described in the paper, with some details, under the name of Cynogale velox, quite sufficiently, especially when one has the type specimen to confirm the description, to establish the specific name of velox. In a note to this description, Du Chaillu observes that, on account of its African habitat and a difference in the shape and proportion of the tail, he thinks it may be the representative of another genus, for which "I proposed the name of Potamogale, preferring, however, to wait until I can procure the skull and skeleton;" so that the statement that "succeeding naturalists have no other choice but to recognize or to reject both alike" is a most erroneous one. I regret to have to make these observations; but a 'Record' is of little use unless it is prepared with care, so that naturalists can place confidence in its accuracy. 


\section{$2 \mathrm{BHL}$ Biodiversity Heritage Library}

1866. "Additions to the Zoophytes of Devonshire." The Annals and magazine of natural history; zoology, botany, and geology 18, 426-426.

View This Item Online: https://www.biodiversitylibrary.org/item/72312

Permalink: https://www.biodiversitylibrary.org/partpdf/61680

\section{Holding Institution}

University of Toronto - Gerstein Science Information Centre

\section{Sponsored by}

University of Toronto

\section{Copyright \& Reuse}

Copyright Status: NOT_IN_COPYRIGHT

This document was created from content at the Biodiversity Heritage Library, the world's largest open access digital library for biodiversity literature and archives. Visit BHL at https://www.biodiversitylibrary.org. 